\title{
Performing Memory - Workers' Strikes in Post-war Poland
}

\author{
Dorota Sosnowska
}

\begin{abstract}
Andrzej Leder, Polish psychoanalyst and philosopher, states that between 1939 and 1956, a revolution took place in Poland. A revolution he calls an 'overslept revolution' (LEDER 2014). To him, it is the time when Polish society entered modernity and changed its model from a feudal to a bourgeois society. He utilizes Jacques Lacan's term trans-passive to underscore the character of Polish revolution: it is perceived as someone else's act, as a nightmare and a sweet phantasy at the same time. This article explores the consequences the workers' protests in Poland between 1945 and 1948, and their performative, or theatrical character. I question how this influences our understanding of common memory and history. Another important philosophical context is Hannah Arendt's On Revolution (1963), and her statement that in any revolutionary act there is a deep division between the mass population and how their goals are formulated. Performative perspective is a way to overcome this division - at least in historical thinking.
\end{abstract}

\section{Keywords}

performance, memory, revolution, workers, PRL 
The Polish People's Republic (PRL) - the totalitarian communist country - was not formally established until 1949. Between the end of the Second World War in 1945 and 1949 the wave of workers' strikes directed against the communist party and new political power flooded Poland and especially Łódź - a city with a significant number of factories, and well-known for its workers' culture. Padraic Kenney describes the historical context of those strikes by recalling the specific situation of Łódź. Just after the war, the workers who had been defending factories (mostly in private hands at that time) from the Germans were the ones to restart production. The act of defending and re-opening the factories was associated with patriotism and heroism on the one hand and slogans of the communist party on the other. Kenney writes: 'In Łódź, as across Poland, workers took the slogans of nationalization at face value and understood the state to mean themselves as they began reconstruction, restarted productions, and elected factory management' (KENNEY 1997: 79).

However, the communists could not allow the factories to be left in the workers' hands. Its goal was to introduce their own people as the managers and administrators of industry in Poland. Given the very bad economic situation of the country at that time, the violent attempts to take over factories had to meet workers' strong resistance. Thus, the strikes in Łódź began.

From what we know, in the period between April of 1945 and December of 1948, there were 306 workers' strikes in Łódź alone (825 in the whole country). One of the biggest and most legendary strikes took place in 1947 in the Poznański textile factory in Łódź. The factory was called 'Częstochowa' before the war, after the Polish city with the famous monastery. It was dominated by female workers known for their religious devotion and very strong relationship with the workplace. After the war the social situation of the factory was not radically different apart from much worse economic conditions.

In 1947, the party wanted to introduce a new procedure in factories called 'multimachine work'. It meant that one worker was supposed to operate two machines instead of one which would allow for the increase of the production and would fulfil the communist's three-year economic plan. Yet, for female workers, it meant not only more work for the same money but also depriving them of their own workspace, their own machine and their sense of security in the factory. When the factory administrators introduced eight 'volunteers' who started the 'multimachine work', the strike began. On September 12, the workers downed tools. They came to the factory as usual, but didn't start their machines. They were waiting for negotiations to start. Kenny writes:

Over the following week, the strike spread to the rest of the factory and then to the rest of the Łódź cotton industry. By the time the strikers went back to work on 25 September, some 40 percent of the city's workers, all in textiles or clothing, had struck in at least 20 factories. The I.K. Poznański cotton mill had always been a center of labor conflict; it was the second largest textile mill in Poland, with approximately 6500 employees compared to the 10000 at Schleiber and Grohman. By 1947, its work force was a mix of experienced operatives, urban women new to factory, and the first arrivals from the countryside. Party leaders considered it hostile territory [...] (KENNEY 1997: 121) 
The strike reached its zenith on the fifth day when the party used a new strategy in the fight with workers.

So far other workers had been able to keep party-members workers from breaking the strike, but now trucks from PPR headquarters rounded up Poznański's PPR (Polska Partia Robotnic$z a$ ) members from their homes in the middle of the night. They were brought to party headquarters where they were coached on their duties, then transported to the factory gates for the first shift. The plan backfired; the rumour mill quickly interpreted the roundup as mass arrests. The same day, a local PPR activist and former member of Poznański's factory council came to the mill to agitate; surrounded by angry workers he struck and pushed one. In the ensuing confusion some twenty-seven women staged a mass fainting - as PPR investigators suggested, probably simulated. This moment of unusual leadership electrified the strike. The women who fainted defused a tense situation, turning attention to reviving the «unconscious» women. At the same time, fainting had the effect of magnifying the incident, lending an aura of mass violence to what may have been a slap on the cheek. Fainting also asserted control of factory space by demonstrating workers' right to do as they pleased at their factory, even to lie unconscious. (KENNEY 1997: 126)

This almost artistic gesture of protesting women reminds contemporary performance art. It materializes the violence which gains its corporal and visual shape. From that moment on, workers from other factories began to strike, requesting information about the situation in Poznański. Very quickly, versions of the story started to circulate. At a certain moment, it was said that pregnant woman are beaten by party operatives in the Poznański factory. The protesters' gender is crucial in this situation. The feminine position - of the one who is weaker and under oppression - is reproduced in theatrical or hysterical way, which exerts an almost electrifying effect. A body falling to the ground is a powerful image, which cruelty is inevitably increased by the fall's repetition. The more graphic elements appear in this story, the more one needs to react, to take immediate action. The effectiveness of the workers' strike is therefore directly linked to the effectiveness of performative gestures, theatrical scenarios performed by the strikers. The ability to conduct a strike is the ability to (re)enact the hidden violence of the power.

But this historical scene becomes even more interesting if one considers the fact that the stories of workers' strikes from this period are still not very well known, if not repressed in Poland. It is due to the censorship and propaganda strategies of the PPR, which couldn't allow its main political figure - the worker - to strike against its order. Although the paradox of Polish history is that it was exactly these workers in Solidarność movement who fought communist regime in the 1980s. As Kenney shows, the government and the communist party acted to dissolve the workers' identity and prevent the formation of a 'workers' class'. Their interest lay in the withdrawal of any political agency from workers, which finally lead to their, again paradoxical, relationship with the catholic church and their refuge in the private sphere of life. But the workers identity - even if weak and deprived of agency - was somehow formed anyway 
as the Solidarność and its strikes were possible couple of decades after the apparent end of the workers class. How was it formed? What were the tools of its preservation?

Only the perspective of the acting body and its performative power allows the history of the workers' movement in its continuity to be fully seen. This perspective is theoretically anchored in contemporary performance studies and its archival turn. With the archive - repertoire dialectic offered by Diana Taylor in her well-known book, The Archive and the Repertoire: Performing Cultural Memory in Americas, this possibility of including the acting body in the set of historical sources appears. She writes:

Insofar as it constitutes materials that seem to endure, the archive exceeds the live. [...] The repertoire, on the other hand, enacts embodied memory: performances, gestures, orality, movement, dance, singing - in short, all those acts usually thought as ephemeral, nonreproducible knowledge. (TAYLOR 2003: 20)

Taylor's concept is clearly based on Rebecca Schneider's 2001 text, Performance Remains, which offered a new definition of performance as such. She raised a key question:

If we consider performance as of disappearance, of an ephemerality read as vanishment and loss, are we perhaps limiting ourselves to an understanding of performance predetermined by our cultural habituation to the logic of archive?

She continues:

According to the logic of the archive, what is given to the archive is that which is recognized as constituting a remain, that which can have been documented or has become document. To the degree that performance is not its own document (as Schechner, Blau, and Phelan have argued), it is, constitutively, that which does not remain. As the logic goes, performance is so radically 'in time'. (SCHNEIDER 2011: 98)

(which is considered linear) that it cannot reside in its material traces and therefore 'disappears'. Schneider proposes another perspective:

Arguably, this sense of performance is imbricated in Phelan's phrasing - that performance 'becomes itself through' disappearance. This phrasing is arguably different from an ontological claim of being (despite Phelan's stated drive to ontology), even different from an ontology of being under erasure. This phrasing rather invites us to think performance as a medium in which disappearance negotiates, perhaps becomes, materiality. (SCHNEIDER 2011: 105).

Performance becomes the most stable machine of memory, the largest archive inscribing the history on the body, suspending the border between what is dead and alive.

Asking if understanding the performance as ephemeral and disappearing is connected to the west, patriarchal and white logic of the archive, Schneider, similarly to Taylor, 
suggests that the other way of understanding it would be especially important for those cultures that were never included in the official history, protected by the power and/or archives. Although both authors underline that the opposition of the archive and performance is not really an opposition as there is no possibility of using the archive without including performative gestures and to see performance without its archival frame, they most certainly suggest that privileged societies can be associated with the archive and those underprivileged with performance and its emancipatory power. I argued in another paper that this premonition is made from the central and not peripheral point of view as archives of the important performances and theatre pieces are crucial for the unprivileged cultures and can be seen in terms of democratisation of access (SOSNOWSKA 2015), but this thought still has great ethical consequences. In order to see those who are deprived of historical archival representation and to hear the voices of those who could not formulate their views in carefully preserved writings, the only possibility for historically anchored identity is to search for the past bodies and their actions - just as the massive fainting during the women's strike in Łódź. I would like to see this performative gesture as a trace, a document or, following Schneider's thought, a re-enactment (of hysterical revolutionary mass or future revolutionary performances) that gives us a glimpse of other repressed history in which what was happening in that historical period was not only the foundation of PRL but also an ongoing revolution. Andrzej Leder - a Polish psychoanalytic and philosopher - defined this revolution as the overslept one. He wrote:

In Poland, between 1939-1956, social revolution happened. Cruel, brutal, imposed from outside, but anyway revolution. It ploughed very deeply into Polish society's tissue, creating the conditions for today's middle class, bourgeoisie. It means then that it paved the road towards the biggest change in centuries in Polish mentality - a withdrawal from the mentality shaped by the countryside and grange towards the mentality determined by the city and its lifestyle. (LEDER 2014:7)

For Leder, this bourgeois revolution, which took place in Poland (mainly in communist times), is overslept because 'it stays absent in thinking', which 'makes it impossible to gain self-consciousness by the middle class' (LEDER 2014: 7).

One of the main characteristics of that revolution is Lacanian transpassivity, which describes a certain lack of agency. Lacan states, that sometimes the acts of the Other can be experienced as one's own, generating the emotional stage which normally accompanies one's own acting. But, at the same time, transpassivity describes the experience of passivity, creating a break between 'I' and my experience, where 'notI' (the Other) is the actual maker of my emotional stage (after LEDER 2014). In Žižek's words: 'My most intimate feelings can be radically externalized; I can literally laugh and cry through another' (ŽIŽEK 2003). In this perspective, the 'overslept' revolution made the dream, as well as the nightmare, come true. Polish society was 'sleeping', not taking an effective part in its own revolution and as a result lacking political agency till today. 
Polish revolution was like overslept. But at the same time, it was the realisation of the cruellest desires. This realisation was accompanied by vindictive satisfaction and - often dramatic - anxiety. Though the revolution is lived in mediation, like in a dream, its results are very real. (LEDER 2014: 17)

For Leder, it means that the Polish middle class is established by the 'disappearance' of the aristocracy on the one hand and Jews on the other as well as by the processes of urbanisation connected to the communist party policies. People from countryside were migrating to cities to work in factories, which was also a part of the strategy used against the working class, preventing the formation of common identity by creating the controlled conflict between the young and the old, those from the city and from the countryside. In the disguise of the proletarian rule, the establishment of the bourgeois society was really taking place, which is one of many paradoxes in Polish social history. As it was not conscious and founded on violence, it is repressed from the societies' imaginary and historical narration.

I argue that looking at the bodies and their actions, finding traces of political performances, one can see the dynamics of social revolution happening in Poland at that time. The striking women in their powerful gesture are such a trace of revolution gleaming in documents and apparently consistent historical discourse. The lack of agency and repressed character of the Polish revolution, which Leder connects with Polish imagery and national phantasms, changes its shape when one looks at history inscribed in bodies and their performances. Strikes, protests and demonstrations were happening in Poland throughout the whole PPR era. They had different dynamics, different rules, diverse symbolism and slogans but they were always a way to re-enact hidden violence and perform it with the use of the bodies. The subject of Polish revolution might not be formed as a class, it might be repressed and lacking agency, but it is indeed performing its own condition in repeated gestures, re-enacted actions and recurrent protests. It means that what is lacking in the language, in the discourse, in the society's imaginary resulting in substantial political crisis in the contemporary Poland is perhaps to reclaim through the memory of performances or the performance memory. This would be the field of research where a different story is being told and a different possibility of being appears.

In her book, On Revolution, Hannah Arendt states that the understanding of revolution as a violent act undertaken in a plea for equality and freedom is deeply influenced by the understanding of politics as oppressing those subjected to it. She shows that the idea of the state of nature where all men are free and equal is in the very contrast with the order of Greek polis (for Arendt the very source of the idea of politics) which was in fact the guarantee of equality and freedom for its citizens, who were not born free and equal at all. She suggests that the object of revolution should be in fact understood as the goal of politics but instead is defined as contrary to it. This is connected to the idea of the new beginning - revolution is supposed to form new political and social order that have never appeared before. She writes: 
The modern concept of revolution, inextricably bound up with the notion that the course of history suddenly begins anew, that an entirely new story, a story never known or told before, is about to unfold, was unknown prior to the two great revolutions at the end of the eighteenth century. Before they were engaged in what then turned out to be a revolution, none of the actors had the slightest premonition of what the plot of the new drama was going to be. However, once the revolutions had begun to run their course, and long before those who were involved in them could know whether their enterprise would end in victory or disaster, the novelty of the story and the innermost meaning of its plot became manifest to actors and spectators alike. (ARENDT 1990: 17)

The result of such a construct is a deep division between the revolutionary masses - defined as hysterical, repetitive, not-individual and feminised by that gesture - and the formulation of revolution's goals which comes from the leaders - those already emancipated from the mass, individual subjects discovering that they are able of introducing new order of freedom. This crack between those who act and those who speak, to put it metaphorically, between the mass and the individual, between the I and the Other, could be described as the transpassivity problem defined by Leder. Is not every revolution is in some way overslept? Is it not always true that masses in violent acts lose their consciousness and then define or remember what happened only by the use of discourse provided by those outside of the mass? This deep division that Arendt describes could be a sign of such a revolutionary condition.

I suggest that in such specific case of historical and political events that engage bodies in violent actions, the bodies should be the main source of the historical narration. They are present in the documents - like female workers form Łódź - or reappear in social, artistic or theatrical practice consisting of performing revolutionary gestures which in order to be effective and recognizable must be repeated triggering what Schneider called 'body-to-body transmission' (SCHNEIDER 2011). From that perspective, the main medium of revolutionary acts is repetition, understood as the way of replaying significant gestures but also as their reproduction in many bodies. The revolution seen from the performance memory perspective, is not anchored in the idea of a new beginning - it is to see as the outburst of repetition. That way it can return to its subject, to the mass, to the multiplicity of the acting hysterical bodies, which establish their identity and history in performance. Is it not a truly ethical dimension of the performances of revolution and/or revolutionary performances? 


\section{Bibliography}

ARENDT, Hannah. 1990. On Revolution. Penguin Books. 1990.

KENNEY, Padraic. 1997. Rebuilding Poland. Workers and Communist 1945-1950. Ithaca and London: Cornell University Press. 1997.

LEDER, Andrzej. 2014. Prześniona rewolucja. Ćwiczenie z logiki historycznej. Warszawa: Wydawnictwo Krytyki Politycznej. 2014.

SCHNEIDER, Rebecca. 2011. Performing Remains: Art and War in Times of Theatrical Reenactment. New York: Routledge. 2011.

SOSNOWSKA, Dorota. 2015. Fake it or re-mix it: performance art history on the peripheries. Maska (2005): 172-174.

TAYLOR, Diana. 2003. The Archive and the Repertoire: Performing Cultural Memory in Americas. Durham: Durham University Press. 2003.

ŽIŽEK, Slavoj. 2003. Will You Laugh for Me, Please?. In These Times (2003). Available online at http://inthesetimes.com/article/88 (accessed 12. 1. 2019)

\section{dr Dorota Sosnowska}

Institute of Polish Culture, University of Warsaw

Krakowskie Przedmieście 26/28, 00-927 Warszawa, Poland

de.sosnowska@uw.edu.pl

Dorota Sosnowska is Adjunct at Institute of Polish Culture, Department of Theatre and Anthropology of Performance, University of Warsaw. She was working on the scientific project under the title 'Sources and Mediations', researching the subject of the relation between theatre and documentation, body and archive, performance and video registration and now is engaged in Polish-German project 'Performing Memory' in frames of which she is researching Polish workers' theatre in context of memory, performance and archival studies. She published articles on the subject in the renowned scientific magazines in Poland as well as in Maska and Performance Research. 